\title{
Reproductive performance and natural antagonists of univoltine population of Ips typographus (Coleoptera, Curculionidae, Scolytinae) at epidemic level: a study from Sumava Mountains, Central Europe
}

\author{
*K. Lukášová, J. Holuša, Š. Grucmanová
}

Department of Forest Protection and Game Management, Faculty of Forestry and Wood Sciences, Czech University of Life Sciences Prague, Kamýcká 129, CZ-16521 Prague 6-Suchdol, Czech Republic, lukasovak@fld. czu.cz,holusa@fld.czu.cz,grucmanova@fld.czu.cz

Abstract: Lukášová K., Holuša J., Grucmanová Š. 2012: Reproductive performance of univoltine population of Ips typographus (Coleoptera, Curculionidae) at epidemic level in Central Europe: case study of small-scale and short-term bark beetles outbreak in the Šumava Mts. - Beskydy, 5 (2): 153-162

Population of I.typographus was studied in one locality with small-scale and short-term outbreak distant from large-scale and long-term outbreak area by several hundred meters. In total, ten spruce trees infested by the spruce bark beetle were examined. Alwaysfourstripes of bark (sample area) with thelength equal to half the circumference of the trunk and the width of approximately $0.5 \mathrm{~m}$ were analyzed. The local spruce bark beetle population was characterized by high population density ( $1.5 \pm 1.2$ entry holes per $\mathrm{dm}^{2}$ ), low number of eggs per female, and short maternal galleries. Relatively low reproductive success $(0.8$ female offspring per one mother beetle, percentage of surviving individuals varies between land $18 \%$ was documented. The parasitism rate of living developmental stages of spruce bark beetle by larval parasitoids averaged $14 \%$. The level of infestation by pathogens and endoparasitoids in maternal beetles from their galleries was low. Highly likely, it is a result of short-term outbreak during which response of parasitoids was delayed in time.

Keywords: spruce bark beetle, Ips typographus, natural enemies, intraspecific competition, epidemic level of population

\section{Introduction}

Over the past century, outbreaks of Ips typographus (Linnaeus, 1758) occurred in many places across Europe (Grégoire, Evans 2004). Since 1950, 2-9 million $\mathrm{m}^{3}$ of wood have been damaged annually by bark beetles, and predominantly by I. typographus (Schelhaas et al. 2003). In the 1990s, outbreaks of the beetle were also documented in places where they had not occurred previously (Grégoire, Evans 2004). Although the forests of the Šumava Mountains had been significantly altered by economic activities over the past centuries, today they are dominated by artificially established forests. During the 1990s, the large-scale outbreak of I. typographus was documented in the central part of the Šumava
Mountains, leading to disintegration of spruce stands. On the Czech side of the border with Germany, two main management approaches were applied during the outbreak. Part of the stands was left without any anthropogenic intervention, and in the remaining area the bands of clear cuts were created near the so-called intervention-free zone (Mánek, Ešnerová 2007). In January 2007, according to to estimates by the admistration of Šumava National Park, the wind storm Kyrill damaged approximately 15,000 $\mathrm{m}^{3}$ of wood in areas of those second zones around the so-called "Calamity Skidway" area. This represents about $20-40$ ha of strongly damaged forest (Svoboda 2007). One year after the wind event, there was a remarkable increase in the 
volume of trees infested by bark beetles. In 2011, more than $235,000 \mathrm{~m}^{3}$ of infested wood was recorded, which is a slight decrease in comparison to 2009 and 2010. In the Šumava Mountains, the outbreak of I. typographus outbreak lasted over 15 years. In cases of such long-term outbreaks, with high population densities of I. typographus retained high above average over many years and absence of management by forestry practices, a significant increase of mortality and parasitism in the beetle is often presumed (Weslien, Schroeder 1999).

The spruce bark beetle Ips typographus is one of the economically most serious pest species of Norway spruce in Eurasia (Christiansen, Bakke 1988). For successful colonization of living trees, a high density of attacking individuals is needed to overcome the defensive system of the trees (Mulock, Christiansen 1986, Christiansen et al. 1987). Reproductive success of the beetles depends on three main conditions: temperature, natural enemies, and inter- as well as intraspecific competition (Faccoli, Bernardinelli 2011). In early stages of the development of the offspring generation significant mortality is caused by predators, i. e. flies of the Medetera genus (Dipútera) with frequency of 0.2-0.26\% (Herard, Mercadier 1996). Also Thanasimus formicarius (Linnaeus, 1758) (Coleoptera) is able to reduce the offspring generation of I. typographus by as much as $18 \%$ (Mills 1985). In the final larval stages and in the pupal stage, parasitoids predominate (Krüger, Mills 1990, Feicht 2004). It is highly likely that at the endemic level predation effectively reduces the beetle density and its population growth. The questions as to whether predation also effectively reduces the epidemic population of the beetle remains open (Kausrud et al. 2012).

In Europe, nine species of pathogens are described as attacking I. typographus (Wegensteiner 2004, Holuša et al. 2009). Although their distribution has been monitored by many authors (survey see Wegensteiner 2004, Takov et al. 2010, Lukášová, Holuša 2012), their influence on population dynamics of the beele is still unknown. When considering parasitism by nematodes, we presume its influence on the rate of development, fertility, survival and flight activity of the beetles (Nickle 1963, Lieutier 1981, Kaya 1984 Tenkáčová, Mituch 1986). Although an influence of nematodes on flight activity of the beetle has not yet been proven (Forsse 1987), fertility may decrease as documented by $20 \%$ reduction of the size of the oocytes in infected females (Thong, Webster 1975).
There are no works evaluating reproductive success in univoltine population of I. typographus in mountain conditions in Central Europe at an epidemic level, except for the studies of parasitism from the Bavarian side of the Šumava Mountains (Kalina 2000, Feicht 2004). There also are no studies dealing with the levels of parasitism, pathogen infections and nematode parasitism among maternal beetles and/or on parasitism of the offspring generation of the beetle.

The purpose of the study was to record the levels of pathogen infection of maternal beetles, parasitism of the offspring, number of predators, and reproductive success of the univoltine generation of I. typographus in small-scale and short-term outbreak with high population density in an area in epidemic level.

\section{Materials and Methods}

\section{Study site}

To evaluate parasitism in the population of I. typographus a special study was carried out at the following three study sites in the locality "Na Ztraceném": Ptačí potok (PP) I-III $\quad\left(48^{\circ} 59^{\prime} 23.617^{\prime \prime} \mathrm{N}, \quad 13^{\circ} 30^{\prime} 40.858^{\prime \prime} \mathrm{E}\right.$; $48^{\circ} 59^{\prime} 11.240^{\prime \prime} \mathrm{N}, 13^{\circ} 30^{\prime} 5.403^{\prime \prime} \mathrm{E}$; and $48^{\circ}$ 59'28.669" N, $13^{\circ} 29^{\prime} 31.022^{\prime \prime} \mathrm{E}$, at elevation $1150 \mathrm{~m}$ a.s.l.) on 23 August 2011. The locality is situated in the area with the epidemic level of $I$. typographus and the forest stand is characterized by $80 \%$ alochtonous trees. The forest is representing by Piceetum acid stands (spruce on acid substrates), i.e. firm, not waterlogged with the presence of small-reed (Calamagrostis spp.) or blueberry (Vaccinium myrtillus). The forest mostly consists of Norway spruce Picea abies (Linnaeus) Karsten, rowan Sorbus aucuparia Linnaeus, and also dwarf pine Pinus mugo Turra on peat-bogs. Most spruce stands inthe locality are 60-80 years old and the original spruce stand was approximately 160 years old. During the period 1991-2007, the area (286ha) was in the intervention regime (man-affected, managed forest), later it was on intervention-free regime. Aboveaverage precipitation $(1,224 \mathrm{~mm}$ per year) and average annual temperature between 5 and $6^{\circ} \mathrm{C}$ is characteristic for this area. First trees infested by I. typographus were found in 2010. The locality with the short-term outbreak of the beetle is distant from long-term ( $>10$ years) outbreak area approximately 700 meters. 


\section{Analysed trees}

At the edges of the sites, there were groups of trees or places with trees infested or already left by bark beetles. Spruce trees infested by bark beetles (presence of entry holes, boring dust, resin on the bark) were selected and felled $(2,2$, and 6 infested trees at each study sites). Diameter of felled trees $\left(\mathrm{d}_{1.3}\right)$ was $29 \mathrm{~cm}$ - median (range $17-33 \mathrm{~cm})$. After the branches removed four distinct sample areas (I-IV) were examined for the presence of I.typographus and its natural enemies on each tree trunk. The sample areas were represented by debarked bands with length equal to the half the tree circumference and the width of approximately $0.5 \mathrm{~m}$. Sample area I was situated $0.5 \mathrm{~m}$ from the tree base, sample area II in the middle between the base and the bottom of the tree's crown, sample area III at the beginning of the crown, and sample area IV in the centre of the crown. Height/length of the trunk, trunk diameter and thickness of the bast and bark in particular samples/sections, and the dimensions of each sample/section were recorded for each tree examined.

\section{Material sampling and data recording}

In each sample area, 10 maternal galleries of $I$. typographus were studied if this was possible, and the number of nuptial chambers (entry holes) was recorded, as was the number of eggs laid by the females, the length of maternal galleries, the number of individuals of the different development stages (larvae of the $1^{\text {st }}-3^{\text {rd }}$ instars, pupae, callow beetles), number of emergence holes, maternal beetles remaining in the gallery. Also the presence of other bark beetle species was recorded.

The average number of eggs per female $( \pm S D$ ) and average length of maternal galleries $( \pm S D$ ) were calculated. The main response variables colonization density, reproductive success and production of I. typographus were summarized using mean values per $\mathrm{dm}^{2}$ of the bark $( \pm S D$ ). Reproductive success was defined as the average number of offspring per mother beetle, calculated as [number of beetles produced. 0.5]/ [number of egg galleries] (Hedgren, Schroeder 2004). Sex ratio was defined as a number of maternal galleries per one nuptial chamber.

The presence and number of larvae and adults of predators of I. typographus were recorded, especially those among Raphidioptera and Medetera (Diptera) and Thanasimus spp. (Coleoptera).

Maternal beetles were collected from each trunk sample area and held under cold conditions $\left(4{ }^{\circ} \mathrm{C}\right)$ in Eppendorf plastic vials. In the laboratory, the beetles were dissected two days after collection, and the native dissections of their visceral organs (especially the digestive system, Malphigian tubules, gonads, fat body) were observed under a light microscope (magnification 100x to 400x, Arsenal LPE 5013i-T) and the presence of viruses, microsporidia, protozoa, nematodes and parasitoids was recorded.

The rate of parasitism of I. typographus by parasitoids (especially by representatives of Hymenoptera: Braconidae, Pteromalidae) was determined by visual examination in the field. The numbers of their larvae, pupae and cocoons of the given groups of Hymenoptera were recorded. The surviving individuals represent the sum of all living stages of bark beetles, and from these the larvae infected by parasitoids were subtracted. The rate of parasitism by parasitoids was calculated as the ratio of the total number of parasitoids (parasitoids larvae on the bark beetle larvae as well as outside bark beetle larvae, cocoons and pupae of the parasitoids in the beetles galleries) to the sum of parasitoids and all the living development stages of the bark beetles.

\section{Data analysis}

Differences in number of parasitoids among trees and percentage of parasitism on tree sample areas (I-IV) were tested using the nonparametric Kruskal-Wallis test. Relationship between the number of entry holes of I.typographus and percentage of parasitism in infested trees was explored by regression analyses. The data were statistically evaluated using Statistica 9.

\section{Results}

The volume of harvested wood infested by bark beetles it the locality "Na Ztraceném" was increasing steadily from $30^{\text {th }}$ June until $15^{\text {th }}$ August 2011, when $9,748 \mathrm{~m}^{3}$ of wood infested by bark beetles (5-72\% rate, depending on the individual segments) was reported in the area of 286 ha. In this second year of outbreak, I. typographus was documented on all infested trees. In average, a total of $34 \mathrm{~m}^{3} /$ ha was infested by bark beetles. The species was present in $87.5 \%$ of all samples. Exceptionally (in two samples), Polygraphus poligraphus (Linnaeus, 1758) was detected. Places not infested by I. typographus were either too dry or covered by the resin, or they were suitable for the beetle (fresh bast) but were not colonized.

The average number of nuptial chambers (entry holes) of I. typographus was $1.5 \pm 1.2$ per $\mathrm{dm}^{2}$ $\left(0-2.8\right.$ holes per $\left.\mathrm{dm}^{2}\right)$. The length of maternal 
galleries was $61.1 \pm 11.4 \mathrm{~mm}$. The average number of eggs per female was 23.1 \pm 4 .4. The population of I. typographus consisted of larvae (L3), pupae and callow beetles. The number of living specimens in various stages (larvae without parasitoids, pupae, callow beetles) was $6.7 \pm 5.4$ individuals per $\mathrm{dm}^{2}$. No emergence holes were observed. The proportion of maternal beetles remaining in the gallery was $11 \%$. Reproductive success was 0.8 daughters (female offspring) per one mother beetle, percentage of surviving individuals varied between 1 and $18 \%$. Sex ratio was 1.4 40.6 .

The average number of predatory larvae of Medetera spp. was $0.2 \pm 0.2$ per $\mathrm{dm}^{2}$. The number of larvae of Thanasimus spp. averaged $0.03 \pm 0.06$ per $\mathrm{dm}^{2}$. Snakefly larvae (Raphidioptera) averaged $0.009 \pm 0.030$ per $\mathrm{dm}^{2}$.

From the 10 trees, a total of 228 live maternal beetles were dissected. The entomopoxvirus ItEPV was detected in the middle intestine of only $3.9 \%$ of those individuals. The microsporidium Chytridiopsis typographi [(Weiser, 1954) Weiser, 1970] was observed only once, in the form of thin-walled cysts within the stomodeum. The neogregarine Mattessia schwenkei (Purrini, 1977) was identified in the fat body in $34.2 \%$ of maternal beetles examined. In the samples, the presence of intestinal (12.4\%) and extraintestinal nematodes (10.8\%) was determined by dissection. In most cases, these were invasive larvae which were very difficult to identify. In $6.5 \%$ of the samples, the species Contortylenchus diplogaster (von Linstow, 1890) Rühm, 1956 was detected.

Only one dead maternal beetle was found in a maternal gallery upon which the hyphal filaments of a fungus from the genus Beauveria were evident.

The eggs of endoparasitoids were detected in $0.4 \%$ of adults of I. typographus. Tomicobia seitneri (Ruschka 1924) in the first larval instar in 1\% of the beetles examined. Not closely specified endoparasitoids were detected in $14.7 \%$ of adults.

Larvae of ectoparasitoids were detected on the larvae of the third instar and pupae of I. typographus, the pupae of Chalcidoids (chalcid flies) from the Pteromalidae family or the cocoons of Braconidae were found only rarely. Adults were observed in two cases only. The average number of ectoparasitoids was $0.9 \pm 1.2$ individuals per $\mathrm{dm}^{2}$, and the average parasitism was $14.3 \pm 18.3 \%$. The average number of parasitoids did not statistically differ among the studied trees (KruskalWallis test: $\mathrm{H}=11.5, \mathrm{p}>0.1$ ). Percentage of parasitism did not differ among particular tree sample areas (Kruskal-Wallis test: $\mathrm{H}=6.5$, $\mathrm{p}>0.5$; Fig. 1).
No statistically significant correlation was found between the number of entry holes and the percentage of parasitism $\left(\mathrm{y}=8.2591+2.8691{ }^{*} \mathrm{x}\right.$, $\mathrm{r}=0.17, \mathrm{p}>0.5 ; \mathrm{R}^{2}=0.0289$ ).

\section{Discussion}

The volume of wood infested by I. typographus and other bark beetle species in the locality "Na Ztraceném" was increasing from the beginning of 2011, growing more than eight times from May to August. In this second year of outbreak, in average $34 \mathrm{~m}^{3} /$ ha was infested by bark beetles. The number of maternal galleries in the studied trees was around 0.4 per $\mathrm{dm}^{2}$ (number of entry holes*sex ratio). This conforms to published data (Komonen et al. 2010) about the large number of maternal galleries in standing trees. In fallen trees the densities of the chambers were $1.24 \pm 0.72 / \mathrm{dm}^{2}$ and $1.62 \pm 1.26 / \mathrm{dm}^{2}$, while in standing trees it was $4.46 \pm 2.07 / \mathrm{dm}^{2}$. As in our data, no significant dependence on tree height (i.e. tree sample area) had been detected earlier by Komonen et al. (2010).

High population densities are also evidenced by the length of the maternal galleries and number of eggs laid. Various authors (e.g. Pfeffer 1952, Martínek 1961, Zumr 1985) have stated different numbers of eggs per female, but the averages range around 60 eggs. Low number of eggs per female (on average $23.1 \pm 4.4$ ) at studied site can be explained by intraspecific competition which increases with growing population density. This is also confirmed by the results of other studies. For example, Anderbrant (1990), Weslien (1994), Grodzki (2004) likewise state that high density leads to a decrease in maternal gallery length and a reduction in the number of eggs laid.

In view of the number of eggs laid and the proportion of stadia living during the study and not parasitized (we are presuming there will no longer be high mortality), the portion of surviving individuals of I. typographus in particular tree sample areas is apparently small (1-18\%). These numbers are, however, completely within the range of the known data. Of the original number of eggs laid, only $7-22 \%$ were surviving to become beetles, according to Thalenhorst (in Klimetzek, Vité 1989). Karpinski (1935) documented the mortality of I. typographus in a range of 96.3 and $98.8 \%$ and affected by various factors during development. Niemeyer (1987) studying the mortality of pre-imaginal stages in situations with 30,000-40,000 larvae per a tree determined the mortality to be approximately $50-75 \%$. Such high larvae mortality in the larvae 


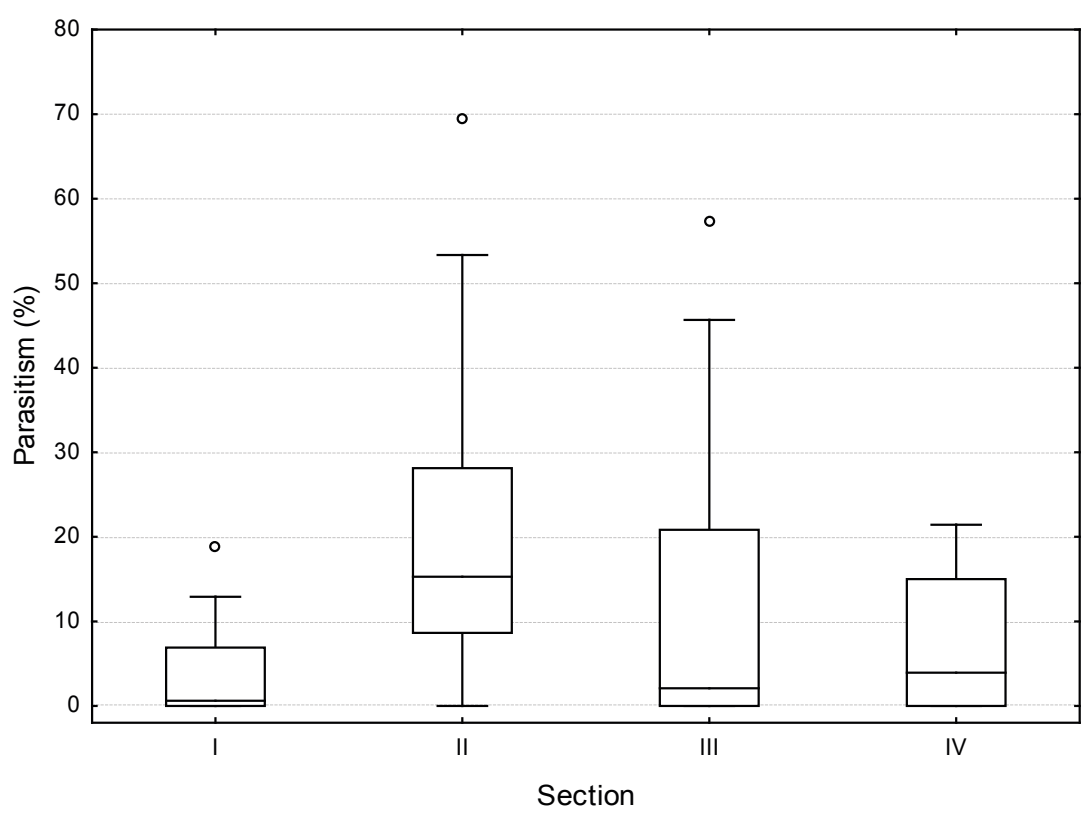

Fig. 1: Percentage of parasitism in I. typographus between tree sample areas I-IV. Box plots show median plus upper and lower quartiles for all three study sites in the Šumava Mts. in 2011. Minimum and maximum values are shown by the upper and lower whiskers (1.5 × interquartile range). Circles indicate outlying values. Sample area I was situated $0.5 \mathrm{~m}$ from the tree base, sample area II at middle distance between the base and the bottom of the tree's crown sample area III at the beginning of the crown, and sample area IV at the center of the crown.

of I. typographus is most probably due to spatial competition. With high population densities, the competition among larvae increases. Fewer offspring then accrue to any individual female (Anderbrant 1990). Although the larvae tend to avoid one another in the galleries (De Jong et al. 1986), in cases of accidental crossing of their galleries cannibalism has been observed (Doležal, Sehnal 2007).

With the approximately determined number of 4 females per $\mathrm{dm}^{2}$ and 6.7 surviving stadia per $\mathrm{dm}^{2}$, the reproductive success is 1.6 stadia per female. This corresponds to the published data. Egg gallery density correlated negatively with reproductive success (Komonen et al. 2010, Faccoli, Bernardinelli 2011, Kausrud et al. 2012). At the density of 0.5 females per $1 \mathrm{dm}^{2}$, more than 20 offspring accrue to the average female; at the density of 31 females per $\mathrm{dm}^{2}$, it is only 0.6 (Anderbrant et al. 1985, Anderbrant, Schlyter 1989). The reproductive success, as measured by number of offspring per female, was greater for down trees (8 \pm 7.5$)$ than standing trees (1.82 \pm 1.18$)$, and this can be explained by higher densities of galleries in the standing trees (Komonen et al. 2010).

At high densities, the duration of development of I. typographus decreases, but pupation always occurs only after ingesting a minimal quantity of food, and thus reaching the minimal weight of the larva. De Jong et al. (1986) state that the minimal length of the larval gallery was $20 \mathrm{~mm}$, at which point the pupae weighed $1.6 \mathrm{mg}$. From this, the influence of the density of maternal and larval galleries per unit of area on the quality of the population can be indirectly inferred (De Jong et al. 1986). Competition resulting from high population densities is therefore considered to be the main factor influencing mortality and fertility of the beetle (De Jong et al. 1986, Anderbrant 1988, 1990, Wermelinger 2004, Faccoli, Bernardinelli 2011).

Due to high elevation and cool climate, there is only one generation of I. typographus documented regularly in the study area (Kalina 2000, Wermelinger 2004). Over the study period, therefore, overwintering maternal beetles as well as their offspring in the stages of higher instar larvae, pupae and callow beetles occurred in low numbers in the galleries during maturation feeding. No emergence holes were observed. This means that the beetles leave the bark and dig into the surrounding area (e.g. forest floor, where they overwinter) only after maturation of their gonads. 
The members of the genus Thanasimus and flies of the genus Medetera are the most common predators of I. typographus, as are parasitic wasps from the families Pteromalidae and Braconidae (Eck 1990, Schopf, Kohler 1995, Weslien, Schroeder 1999, Hulcr 2001, Wermelinger 2002, Zelený 2007). The rate of occurrence of natural enemies in general, depends on a host tree species and even varies by a individual tree, as the bark texture is especially important (Lawson et al. 1997). The quantities of predators, pathogens and parasitoids correspond to the beetles' population density, but their response can be delayed by weeks or even as much as a year (Kausrud et al. 2012).

In this small-scale and short-term outbreak with high population density of I. typographus in an area in epidemic level the pathogenic infections of the maternal beetles are not high. For example, a common microsporidium C. typographi (Wegensteiner 2004, Takov et al. 2010) was determined only in one case, and ItEPV infection was also not high (3.9\% of analysed individuals), even though Šumava locations have been among the places with very high infection (Weiser et al. 2000, Weiser 2002). A higher level of infection was displayed by the neogregarine M. schwenkei (34.2\% of maternal beetles). This data can be overestimated. However, as it concerns beetles which remained in the galleries and never left them; such beetles could be affected by $M$. schwenkei infection occurring in the fat body in the form of scaphoid spores. All this, theoretically, may influence the tendency of beetles to emerge. It is presumed that only newly infected individuals leave the galleries, and therefore the pathogen occurs at higher rates towards the end of the vegetation season (Weiser 2002). The obtained data about pathogenic organisms (percentages) correspond with and/or are almost identical to the previous findings from the Šumava Mountains (Weiser et al. 2000).

The absence of the eugregarinida Gregarina typographi (Fuchs, 1915) is very surprising, as it is one of the most common pathogens of bark beetles (Wegensteiner 2004, Takov et. al. 2010) which is very intensively transferred in nuptial chambers of the beetle (Lukášová, Holuša 2011). Such absence, documented also in the populations with high densities of the beetle, is caused by the absence of those infections in the initial populations, Parasitism by entomophagous nematodes was greater than expected. For example, Tenkáčová, Mituch (1986, 1987, 1991) report from various locations (e.g. the Tatra National Park), report the presence of nematodes in bark beetles in the range of $4.3-5.1 \%$ of individuals examined. In the case of I. typographus in the Šumava National Park, higher values of parasitism by nematodes might be explained by the high density of the beetle population easily accessible to nematodes. In the case of Contortylenchus diplogaster, the given studies report its occurrence in about $9 \%$ of I. typographus individuals in the spring generation and slightly under $1 \%$ in the summer generation. The obtained data on the parasitism by this nematode species in the study area confirm to the known findings.

When evaluating the total rate of parasitism, it is necessary to observe how its values change on within individual trees, as even at relatively high levels of parasitism such rate only occurs in a small percentage of samples while the rest samples show very low parasitism (Hougardy, Grégoire 2001). Eck (1990) reported, for example, that if while infestation ranged between $0 \%$ and $70 \%$ more than half of the wood samples showed mortality of I. typographus below $5 \%$. In the study area this was similar. T.seitneri responds to the I. typographus aggregation pheromone (Faccoli 2000). It is a common endoparasitoid in the adults (Eck 1990), but the rate of parasitism is low, i.e. 0-9.5\% (Feicht 2004). The data in this instance fall entirely within the expected range, even though it concerns only larvae of the first instar, where the species affiliation is clear. In some cases, the total parasitism can reach 20$50 \%$ (Faccoli 2000). Other endoparasitoid larvae cannot be identified precisely. We can presume the samples to include the presence of another common species of endoparasitoid Ropalophorus clavicornis (Wesmael, 1835) (Faccoli 2001,Wermelinger 2002, Zelený 2007).

Most parasitoids of the Scolytinae are among the ectoparasitoids of larvae and attack their hosts through the bark (Kenis et al. 2004). Within the same tree, the representatives of Pteromalidae and Braconidae are predominate on the upper part of the trunk (with lower tree diameter), where the bark is thinner and smoother (Wermelinger 2002). In our study percentage of parasitism did not differ among trees section. This is probably the result of comparable bast and bark thickness of the trees, which did not vary much in the particular sections.

The parasitism rate most often varies in the range of 5-55\% (Mills 1986, Eck 1990, Wermelinger 2002, Feicht 2004), but it can be even higher (Weslien 1992, Markovic, Stojanovic 2003). Parasitism rate in this study is near the lower limit of the published data outbreak 


\section{Acknowledgments}

The research was supported by the Forest Protection Service and project NAZV QH81136 of the Ministry of Agriculture of the Czech Republic.

\section{References}

Anderbrant, O. 1988: Survival of parent and brood adult bark beetles, Ips typographus, in relation to size, lipid content and re-emergence or emergence day. Physiological Entomology, 13: 121-129.

ANDERBRANT, O. 1990: Gallery construction and oviposition of the bark beetle Ips typographus (Coleoptera: Scolytidae) at different breeding densities. Ecological Entomology, 15: 1-8.

Anderbrant, O., Schlyter, F. 1989: Causes and effects of individual quality in bark beetles. Ecography, 12: 488-493.

Anderbrant, O., Schlyter, F., Birgersson, G. 1985: Intraspecific competition affecting parents and offspring in the bark beetle Ips typographus. Oikos, 45: 89-98.

Christiansen, E., BakKe, A. 1988: The spruce bark beetle of Eurasia. In: BerRyman, A. (ed.) Dynamics offorestinsect populations, Plenum Publishing Corporation, 480-503.

Christiansen, E., Waring, R.H., Berryman, A. A. 1987: Resistance of conifers to bark beetle attack: searching for general relationship. Forest Ecology and Management, 22: 89-106.

De Jong, M. C. M., Grijpma, P. 1986: Competition between larvae of Ips typographus. Entomologia Experimentalis et Applicata, 41: 121-133.

Doležal, P., Sehnal, F. 2007: Effects of photoperiod and temperature on the development and diapause of the bark beetle Ips typographus. Journal of Applied Entomology, 131: 165-73.

EcK, R. 1990: Die parasitischen Hymenopteran des Ips typographus in der Phase der Progradation. Entomologische Abhandlungen, 53: 152-178.

FAccoli, M. 2000: Notes on the biology and ecology of Tomicobia seitneri (Ruschka) (Hymenoptera: Pteromalidae), a parasitoid of Ips typographus (L.) (Coleoptera: Scolytidae). Frustula Entomologica, 23: 47-55.

FAcCOLI, M. 2001:Tomicobia seitneri (Ruschka), Ropalophorus clavicornis (Wesmael) and Coeloides bostrychorum Giraud: three hy- menopterous parasitoids of Ips typographus (L.) (Col., Scolytidae) new to Italy. Bollettino della Societa Entomologica Italiana, 133: 237-246.

Faccoli, M., Bernardinelli, I. 2011: Breeding performance of the second generation in some bivoltine populations of Ips typographus (Coleoptera Curculionidae) in the south-eastern Alps. Journal of Pest Science, 84:15-23.

Feicht, E. 2004: Parasitoids of Ips typographus (Col., Scolytidae), their frequency and composition in uncontrolled and controlled infested spruce forest in Bavaria. Journal of Pest Science, 77: 165-172.

ForsSE, E. 1987: Flight duration in Ips typographus L.: Insensitivity to nematode infection. Journal of Applied Entomology, 104: 326-328.

Grégoire J. C., Evans H. F., 2004: Damage and control of BAWBILT organisms-an overview. In: Lieutier F., Day K. R., Battisti A., GréGoire J. C., Evans H. F. (eds): Bark and wood boring insects in living trees in Europe, a synthesis. Kluwer Academic Publishers: Dordrecht, the Netherlands, 19-37.

GrodzKI, W. 2004: Some reaction of Ips typographus (L.) (Col.: Scolytidae) to changing breeding conditions in a forest decline area in the Sudeten Mountains, Poland. Journal of Pest Science, 77: 43-48.

Hedgren, P. O., Schroeder, L. M. 2004: Reproductive success of the spruce bark beetle Ips typographus (L.) and occurrence of associated species: a comparison between standing beetle-killed trees and cut trees. Forest Ecology and Management, 203: 241-250.

Herard, F., Mercadier, G. 1996: Natural enemies of Tomicus piniperda and Ips acuminatus (Col., Scolytidae) on Pinus sylvestris near Orléans, France: Temporal occurrence and relative abundance, and notes on eight predatory species. Entomophaga, 41: 183-210.

HoluŠA, J., Weiser, J., ŽižKA, Z. 2009: Pathogens of the spruce bark beetles Ips typographus and Ips duplicatus. Central European Journal of Biology, 4: 567-573. 
Hougardy, E., GrégoIre, J.C. 2001: Bark-beetle parasitoids population surveys following storm damage in spruce stands in the Vosges region (France). Integrated Pest Management Reviews, 6: 163-168.

HulcR, J. 2001: Přirození regulátoři lýkožrouta smrkového (Ips typographus L.) na Šumavè. [Natural regulators of spruce bark beetle (Ips typographus L.) in the Šumava Mts.]. Bakalářská práce, Biologická fakulta Jihočeké univerzity v Českých Budějovicích, 39 s.

Kalina, V. 2000: Mortalita lýkožrouta smrkového (Ips typographus L.) v průběhu vývoje pod kưrou v Národním parku Šumava a její ovlivňování blanokřídlými parazitoidy (Hymenoptera: Pteromalidae; Braconidae). In: PodrÁzský, V., RYšÁnKová, H., VAcek, S., Ulbrichová, I. (eds.) Monitoring, výzkum a management ekosystému Národního parku Šumava. Sborník celostátní konference. Kostelec nad Černými lesy 27. A 28. Listopadu 2000.

KARPIŃSKI, J. J. 1935: Przyczyny ograniczaja cerozmnażani esie korników drukarzy (Ips typographus L.i Ipsduplicatus Salhb.) w lesie pierwotnym. Instytut Badawczy Lasów Państwowych, Warszawa, Ser. A,15, $86 \mathrm{~s}$.

Kausrud, K., Okland, B., Skarpaas, O., Grégoire, J.C., Erbilgin, N., Stenseth, N. C. 2012: Population dynamics in changing environments: the case of an eruptive forest pest species. Biological Reviews, 87: 34-51.

KAYA, H. K. 1984: Nematode parasites of bark beetles. In: NickLe, W. R. (ed.) Plant and Insect Nematodes. New York, Marcel Dekker, Inc., 727-754.

Kenis, M., Wermelinger, B., Grégoire, J. C. 2004: Research on parasitoids and predators of Scolytidae - a review. In: LiEutier, F., DAY, K. R., Battisti, A., Grégoire, J. C., Evans, H. F. (eds.) Bark and wood boring insects in living trees in Europe, a synthesis, Dordrecht, Kluwer Academic Publishers, 237-290.

Klimetzek, D., Vité, J.P. 1989: Tierische Schädlinge. In: Schmidt-Vogt, H. (ed.) Die Fichte Bd. II/2 Krankheiten, Schäden, Fichtensterben. Verlag Paul Parey, Hamburg and Berlin, 607 pp.

Komonen, A., Schroeder, L. M., Weslien J. (2010): Ips typographus population development after a severe storm in a nature reserve in southern Sweden. Journal of Applied Entomology, 135 (1-2): 132-141.

KRÜGER, K., Mills, N. J. 1990: Observations on the biology of three parasitoids of the spruce bark beetle, Ips typographus (Col., Scolytidae): Coeloides bostrychorum, Dendrosoter midderndorffii (Hym., Braconidae) and Rhopalicus tutela (Hym., Pteromalidae). Journal of Applied Entomology, 110: 281-291.

Lawson, S. A., Furuta, K., Katagiri, K. 1997: Effect of natural enemy exclusion of Ips typographus japonicus Niijima (Col., Scolytidae). Journal of Applied Entomology, 121: 89-98.

Lieutier, F. 1981: Influence des nématodes parasites surl'essaimage du scolytide Ips sexdentatus (Boern.). Action régulatrice du froid. Acta Oecologica, Oecologia Applicata, 2: 357-368.

LuKÁšovÁ, K., HolušA, J. 2011: Gregarina typographi (Eugregarinorida: Gregarinidae) in the bark beetle Ips typographus (Coleoptera: Curculionidae): changes in infection level in the breeding system. Acta Protozoologica, 50: 311-318.

LuKÁšová, K., HolušA, J. 2012: Patogeny lýkožroutů rodu Ips (Coleoptera: Curculionidae: Scolytinae): review. [Pathogens of bark beetles of the genus Ips (Coleoptera: Curculionidae: Scolytinae): review]. Zprávy lesnického výzkumu, in press.

MÁNeK, J., EšnerovÁ, J. 2007: Studium genetické variability a ověřování původnosti smrkových populací v Národním parku Šumava jako podklad pro záchranná managementová opatření. [Study of genetic variability of Norway spruce populations (Picea abies (L.) Karst.) in the Šumava National Park and verification of their origin as a basis for conservation measures]. In: DvoŘÁK, L., Šustr, P., BRAun, V. (eds.) Aktuality šumavského výzkuтu III. Sborník z konference Srní 4.-5.10. 2007. Vimperk: Správa Národního parku a Chráněné krajinné oblasti Šumava, 87-89.

Markovic, C., Stojanovic, A. 2003: Significance of parasitoids in the reduction of oak bark beetle Scolytus intricanus Ratzeburg (Col., Scolytidae) in Serbia. Journal of Applied Entomology, 127: 23-28.

MartíneK, V. 1961: Problém natality a gradace kưrovce Ips typographus $L$. ve střední Evropě. Rozpravy Československé Akademie Véd, Řada MPV, 71: 1-78.

Mills, N. J. 1985: Some observations on the role of predation in the natural regulation of Ips typographus populations. Journal of Applied Entomology, 99: 209-215.

Mills, N. J. 1986: A preliminary analysis of the dynamics of within tree populations of Ips typographus (L.) (Coleoptera Scolytidae). Journal of Applied Entomology, 102: 402-416.

Mulock, P., Christiansen, E. 1986: The threshold of successful attack by Ips typographus on Picea abies: a field experiment. Forest Ecology and Management, 14: 125-132. 
NicKLe, W. R. 1963: Observations on the effect of nematodes on Ips confusus (LeConte) and other bark beetles. Journal of Insect Pathology, 5:386-389.

Niemeyer, H. 1987: Erfahrungen mit der Bekämpfung rindenbrütender Borkenkäfer. Allgemeine Forst und Jagdzeitung, 98: 29-31.

Pfeffer, A. 1952: Kưrovec lýkožrout smrkový a boj proti пёmu. [Spruce bark beetle and control]. Nakladatelství Brázda, Praha, 45 s.

SchelhaAs, M.J., NabuURs, G.J., SchucK, A. 2003: Natural disturbances in the European forests in the 19th and 20th centuries. Global Change Biology, 9: 1620-1633.

SCHOPf, R., KöHLER, U. 1995: Untersuchungen zur Populationsdynamik der Fichtenborkenkäfer im Nationalpark Bayerischer Wald. Nationalpark Bayerischer Wald - 25 Jahre auf dem Wegzum Naturwald. Nationalpark verwaltung Bayerischer Wald: Neuschönau, 88-110.

Svoвoda, M. 2007: Efekt disturbance a hospodářských zásahů na stavlesního ekosystému - případová studie z oblasti tzv. Kalamitní svážnice na Trojmezné. [Effects of disturbances and management on the forest ecosystem - case study from the area of Trojmezná old-growth forest]. In: DvoŘÁk, L., Šustr, P. , BRAun, V. (eds.) Aktuality šumavského výzkumu III. Sborník z konference Srní 4.-5.10. 2007. Správa Národního parku a Chránèné krajinnéoblasti Šumava: Vimperk, 109-114.

Takov, D., Pilarska, D., Wegensteiner, R. 2010: List of protozoan and microsporidian pathogens of economically important bark beetle species (Coleoptera: Curculionidae: Scolytinae) in Europe. Acta Zoologica Bulgarica, 62: 201-209.

TenKÁčová, I., Mituch, J. 1986: Príspevok k poznaniu nematofauny chrobákov čeladě Scolytidae na smreku obyčajném v Košickém lesnom parku. Lesnický časopis, 32: 381-387.

TenkÁčovÂ, I., Mituch, J. 1987: Nematodes new for the fauna of the Czechoslovak Socialist Republic with the affinity to scolytids (Coleoptera: Scolytidae). Helmintologia, 24: 281-291.

Tenkáčová, I., Mituch, J. 1991: Nematoda podkornikovitých (Coleoptera: Scolytidae) z Vysokých Tatier. Zborník prác o Tatranskom národnom parku, 31: 173-182.

Thong, C. H. S., Webster, J.M. 1975: Effects of the Bark Beetles Nematode, Contortylenchus reversus on Gallery Construction, Fecundity and Egg Viability of the Douglas Fir Beetle Dendroctonus pseudotsugae (Coleoptera: Scolytidae). Journal of Invertebrate Patho$\log y, 26: 235-238$.
Wegensteiner, R. 2004: Pathogens in bark beetles. In: Lieutier, F., Day, K. R., Battisti, A., GrÉgoire, J. C., Evans, H.F. (eds.) Bark and wood boring insects in living trees in Europe, a synthesis. Kluwer Academic Publishers, Dordrecht, 291-313.

WeIser, J. 2002: Patogenní organismy. In: SKuHRaVÝ, V. (ed.) Lýkožrout smrkový (Ips typographus L.) a jeho kalamity. Der Buchdrucker und seine Kalamitäten. [Spruce bark beetle (Ips typographus) and its outbreaks]. Agrospoj, Praha, 97-100.

Weiser, J., Pultar, O., ŽIŽKa, Z. 2000: Biological protection of forest against bark beetle outbreaks with poxvirus and other pathogens. IUAPPA, Section B: 168-172.

WeRMELINGER, B. 2002: Development and distribution of predators and parasitoids during two consecutive years of an Ips typographus (Col., Scolytidae) infestation. Journal of Applied Entomology, 126: 521-527.

Wermelinger, B. 2004: Ecology and management of the spruce bark beetle Ips typographus-a review of recent research. Forest Ecology and Management, 202: 67-82.

WesLIEN, J. 1992: The arthropod complex associated with Ips typographus (L.) (Coleoptera, Scolytidae): species composition, phenology, and impact on bark beetle productivity. Entomologica Fennica, 3: 205-213.

Weslien, J. 1994: Interactions within and between species at different densities of the bark beetle Ips typographus and its predator Thanasimus formicarius. Entomologia Experimentalis et Applicata, 71: 133-143.

Weslien, J., Schroeder, L. M., 1999: Population levels of bark beetles and insects in managed and unmanaged spruce stands. Forest Ecology and Management, 111:267-275.

ZeLenÝ, J. 2007: Predátoři a parazitoidi lýkožrouta smrkového (Ips typographus) na Šumavě. In: DvoŘÁK, L., ŠUstr, P., BRAUN V. (eds.) Aktuality šumavského výzkumu III. Sborník z konference Srni 4.-5.1.0 2007. Správa Národního parku a Chránèné krajinné oblasti Šumava, Vimperk, 72-74.

Zumr, V. 1985: Biologie a ekologie lýkožrouta smrkového (Ips typographus) a ochrana proti nému. [Biology and ecology of eight-toothed spruce bark beetle (Ips typographus L.), and forest protection measures]. Academia, Praha, 124 s. 